\title{
Persentase Motilitas dan Viabilitas Spermatozoa Kambing Sapera dalam Pengencer Tris Kuning Telur dan Susu Skim Kuning Telur Before Freezing
}

\author{
(PERCENTAGE MOTILITY AND VIABILITY SPERMATOZOA OF SAPERA GOAT IN \\ TRIS EGG YOLK AND SKIM MILK EGG YOLK BEFORE FREEZING)
}

\author{
Herlina Masyitoh $^{1 *}$, Tri Wahyu Suprayogi², Ratih Novita Praja ${ }^{3}$, Pudji Srianto², Sri \\ Pantja Madyawati ${ }^{2}$, Amung Logam Saputro ${ }^{4}$ \\ ${ }^{1}$ Bachelor of Veterinary Medicine, \\ ${ }^{2}$ Department of Veterinary Reproduction, \\ ${ }^{3}$ Department of Veterinary Microbiology, \\ ${ }^{4}$ Department of Clinic and Animal Hospital, \\ Faculty of Veterinary Medicine, Universitas Airlangga, \\ UNAIR C-Campus Mulyorejo, Surabaya, Jawa Timur, Indonesia, 60115 \\ Telp. (031)5993016, Fax. (031)5993015 \\ *Corresponding author: herlina.masyitoh-2014@ @kh.unair.ac.id
}

\begin{abstract}
Abstrak
Penelitian ini bertujuan untuk mengetahui perbedaan persentase motilitas dan viabilitas semen kambing Sapera terhadap evaluasi semen segar dan before freezing dengan penambahan pengencer tris kuning telur dan susu skim kuning telur. Metode penelitian ini adalah pengambilan semen, evaluasi semen segar (pemeriksaan makroskopis dan mikroskopis), pengenceran semen, gliserolisasi, ekuilibrasi dan evaluasi before freezing. Penelitian ini terdiri dari P0, P1 dan P2, masing-masing perlakuan terdiri dari sembilan ulangan. P0 adalah semen segar kambing Sapera, P1 adalah semen kambing Sapera+pengencer tris kuning telur dan P2 adalah semen kambing Sapera+pengencer susu skim kuning telur. Data yang diperoleh dengan Uji T2 sampel dependent, membandingkan P0 dan P1 serta P0 dan P2. Data menunjukkan perbedaan sangat nyata $(\mathrm{p}<0,01)$ pada perlakuan P0 dan P1 persentase motilitas 76,11\%; 65,56\% dan viabilitas 82,33\%; 72,22\%. P0 dan P2 persentase motilitas $76,11 \%$; $61,11 \%$ dan viabilitas $82,33 \%$; $67,78 \%$. Hasil tersebut menunjukkan bahwa penelitian persentase motilitas dan viabilitas spermatozoa kambing Sapera mengalami penurunan dari semen segar pada tris kuning telur dan susu skim kuning telur before freezing.
\end{abstract}

Kata kunci: spermatozoa, kambing Sapera, tris kuning telur, susu skim kuning telur, before freezing

\begin{abstract}
This study aimed to determine the percentage difference motility and viability of spermatozoa Sapera goat in evaluation of fresh semen and before freezing by adding diluent tris egg yolk and milk skim egg yolk. This research method are collecting semen, fresh semen macroscopic and microscopic examination, semen dilution, gliserolisation, equilibration and evaluation before freezing. This study consisted of P0, P1 and P2, treatment respectively consisted of nine replicates. PO is fresh goat semen Sapera, P1 is semen Sapera+tris egg yolk and P2 is semen Sapera+skim milk egg yolk. The data obtained with T2 samples dependent, comparing PO and $P 1$ and $P 0$ and $P 2$. Data showed highly significant differences $(p<0,01)$ in treatment $P 0$ and $P 1$ with percentage motility $76,11 \% ; 65,56 \%$ and viability $82,33 \% ; 72,22 \%$. P0 and $P 2$ with percentage motility $76,11 \%$; $61,11 \%$ viability and $82,33 \%$; 67,78\%. It can be conclued that percentage motility and viability of spermatozoa goat Sapera decreased from fresh semen in tris egg yolk and skim milk egg yolk before freezing.
\end{abstract}

Key words: spermatozoa, Sapera goat, tris egg yolk, egg yolk skim milk, before freezing

\section{PENDAHULUAN}

Produksi susu nasional pada tahun 2016 tercatat 852.951 ribu ton atau meningkat $2,13 \%$ dibandingkan produksi tahun sebelumnya, peningkatan ini bisa terjadi karena peningkatan populasi dari ternak penghasil susu seperti sapi dan kambing. Populasi ternak kambing yang 
mengalami peningkatan pada tahun 2012 jumlahnya mencapai 17.905.862 ekor dan tahun 2016 mengalami peningkatan 19.608.181 ekor dengan populasi terbesar di Propinsi Jawa Tengah, Jawa Timur, Jawa Barat dan Lampung (Ditjennak, 2016).

Salah satu penopang susu nasional berasal dari susu kambing, walaupun tidak sebanyak susu sapi. Susu kambing memiliki keunggulan yaitu butiran lemak yang kecil dan homogen sehingga mudah di cerna dan kandungan vitamin A, B3, B6, B12, dan D lebih tinggi dibandingkan susu sapi (Sutama dan Budiarsana, 2017). Sutama dan Budiarsana (2017) menjelaskan ada beberapa kambing perah yang menghasilkan susu di Indonesia meliputi Peranakan Etawa (PE), Saanen dan Sapera (persilangan Saanen dengan Peranakan Etawa).

Menurut Supriyati dkk. (2015) bahwa kambing Sapera memproduksi susu antara 2-4 liter/hari lebih tinggi dibandingkan kambing PE yang bervariasi antara 2-3 liter/hari (Soetarno, 2016). Keragaman produksi susu diatas dipengaruhi beberapa faktor seperti keturunan, lingkungan, nutrisi dan manajemen pemeliharaan (Praharani, 2013). Permintaan akan susu kambing terus meningkat setiap tahunnya, Ditjen Peternakan telah melakukan sejumlah upaya untuk mendorong pengembangbiakan ternak kambing perah dengan teknologi inseminasi buatan (IB).

Inseminasi buatan (IB) merupakan teknik memasukkan semen kedalam saluran reproduksi betina dengan menggunakan alat khusus yang disebut insemination gun. Tujuan dari inseminasi buatan (IB) adalah untuk menunjang peningkatan genetik ternak, untuk peningkatan populasi, produksi ternak, peningkatan pendapatan peternak, dan mengurangi penyakit kelamin yang menular (Hardijanto, dkk., 2010). Semen yang digunakan IB pada umumnya menggunakan semen beku (frozen semen), karena penyimpanan bisa dalam jangka waktu yang panjang. Pengencer pada umumnya menggunakan tris kuning telur dan susu skim kuning telur, karena pengencer tersebut telah memenuhi syarat pengenceran yang mengandung nutrisi untuk spermatozoa, melindungi membran spermatozoa dari cold shock, dan bersifat buffer (Ari et al., 2011).

Pengencer kuning telur yang mengandung lipoprotein dan fosfolipid seperti fosfatidikolin yang mempertahankan serta mencegah kerusakan membran sperma pada proses pembekuan dan susu skim memiliki kasein yang dapat melindungi spermatozoa selama penyimpanan pada suhu rendah (Allai et al., 2015).

Proses sebelum pembekuan dilakukan gliserolisis dengan penambahan gliserol yang bersifat krioprotektan intraseluler yang mencegah terjadinya kristalisasi dan tertimbunnya elektrolit intraseluler di dalam spermatozoa dan dapat mengurangi kerusakan sel spermatozoa, kemudian proses equilibrasi atau proses penyesuaian spermatozoa terhadap gliserol sebelum dilanjutkan pada tahap pembekuan dilakukan evaluasi before freezing (evaluasi sebelum pembekuan) (Hardijanto, dkk., 2010). Evaluasi before freezing bertujuan untuk melihat kelayakan semen yang akan dibekukan dan pengaruh bahan-bahan tambahan dalam mempertahankan spermatozoa pada proses pendinginan, semen yang layak akan dilakukan proses pembekuan. Kualitas semen beku akan mendapatkan hasil yang baik jika kualitas dari spermatozoa pada proses sebelum pembekuan berada pada standar untuk dibekukan, sehingga perlunya dilakukan pemeriksaan before freezing.

Kambing Sapera memiliki kualitas susu yang baik sehingga perlu dikembangkan dengan pembuatan semen beku agar mendapatkan bibit unggul kambing Sapera untuk penghasil susu, sebelum dilakukan tahap pembekuan semen kambing Sapera harus dilakukan evaluasi before freezing, untuk melihat kualitas spermatozoa kambing Sapera pada bahan pengenceran, proses gliserolisasi dan equilibrasi. Evaluasi before freezing ini menggunakan bahan pengencer tris kuning telur dan susu skim kuning telur dengan parameterpersentasemotilitas dan viabilitas spermatozoa kambing Sapera. 


\section{METODE PENELITIAN}

\section{Alat dan Bahan}

Sampel penelitian ini menggunakan semen dari 1 ekor kambing Sapera berumur 2 tahun yang diambil 2 kali dalam satu minggu. Bahan yang digunakan untuk pemeriksaan makroskopis dan mikroskopis: $\mathrm{NaCl}$ fisiologis, Eosin Negrosin. Bahan pengenceran susu skim : Susu bubuk skim Tropicana Slim 10gr, aquades 100ml, antibiotik Penicilin 1000IU/ml, streptomicin 1mg/ml, Alkohol 70\%, kuning telur $5 \mathrm{ml}$. Bahan pengenceran tris kuning telur : Aquades $80 \mathrm{ml}$, laktosa 1.4gr, antibiotik (Penicilin dan Streptomicin) $1.000 \mathrm{IU} / \mathrm{ml}$, tris amino methane $1.6 \mathrm{gr}$, raffinosa $2.5 \mathrm{ml}$, asam sitrat $0.9 \mathrm{ml}$ dan kuning telur $20 \mathrm{ml}$.

\section{Penampungan Semen Kambing Sapera}

Pengambilan semen dilakukan dengan menggunakan vagina buatan, sebelum dilakukan penampungan preputium dibersihkan menggunakan air hangat.

\section{Pemeriksaan Semen Segar}

Pemeriksaan makroskopis meliputi: volume, bau, pH, warna dan konsistensi. Volume dapat diketahui dengan cara melihat skala pada tabung penampungan semen, warna dengan melihat semen di tabung penampungan, dalam menentukan bau semen dapat dengan indra pembau yang didekatkan pada tabung yang berisi semen.pH pengukuran $\mathrm{pH}$ semen dengan menggunakan kertas lakmus dan konsistensi (kekentalan), cara mengetahui kensistensi semen dengan tabung yang berisi semen dimiringkan dan dikembalikan pada posisi semula.

Pemeriksaan mikroskopis meliputi motilitas, viabilitas dan konsentrasi. Motilitas terbagi atas 2 yaitu motilitas massa dan individu, konsentrasi spermatozoa dilakukan dengan menggunakan spektrofotometer.

\section{Pembuatan Pengencer Tris Kuning Telur}

Persiapkan bahan yang digunakan untuk pengencer tris kuning telur terdiri dari :tris amino methane, asam sitrat, laktosa, raffinosa, kuning telur, aquades, antibiotik dan gliserol.
Pengencer ini dibagi menjadi dua bagian yaitu pengencer $\mathrm{A}$ dan pengencer $\mathrm{B}$. Pengencer $\mathrm{B}$ terdiri dari pengencer $\mathrm{A}+$ gliserol $10 \%$ dari total volume diluter.

\section{Pengencer Susu Skim Kuning Telur}

Pengencer susu skim menggunakan bahan susu skim, aquades, antibiotik, kuning telur dan gliserol. Pengencer ini dibagi menjadi dua bagian: bagian pengencer $\mathrm{A}$ dan pengencer $\mathrm{B}$. Pengencer A terdiri dari susu skim, aquades, kuning telur, antibiotik. Pengencer B terdiri dari pengencer A gliserol sebanyak 10\% dari total volume diluter.

\section{Pengamatan Penelitian}

Pemeriksaan motilitas dilakukan dengan meneteskan spermatozoa ke obyek glass kemudian ditutup dengan cover glass dan diamati di bawah mikroskop untuk melihat gerakan (maju/progresif) spermatozoa.

$\%$ motilitas $=\frac{\text { jumlah spermatozoa yang progresif }}{\text { total jumlah spermatozoayang diamati }} x 100$

Pemeriksaan viabilitas spermatozoa dengan menggunakan perwarnaan eosin negrosin akan mewarnai spermatozoa yang mati karena lapisan lipid pada spermatozoa telah rusak, sedangkan untuk spermatozoa yang hidup tidak terwarnai atau transparan.

$\%$ viabilitas $=\frac{\text { jumlah spermatozoa yang tidak terwarnai }}{\text { total jumlah spermatozoa yang diamati }} \times 100$

\section{Analisis Data}

Data yang diperoleh dianalisis dengan menggunakan analisis statistika yaitu Uji T2 Sampel dependent. Pengolahan data dengan IBM SPSS Statistic 22 (Statistical Program for Social Science) (Al-arif, 2016).

\section{HASIL DAN PEMBAHASAN}

Pemeriksaan makroskopis dan mikroskopis dilakukan setelah penampungan semen untuk melihat kelayakan sampel yang akan diberi perlakuan. Hasil pemeriksaan dapat dilihat pada tabel 1. 
Hasil ini menunjukkan rataan volume $0,94 \pm 0,39$, hasil ini menunjukkan lebih tinggi dari penelitian Hastono dkk., (2013) dengan hasil 0,59 $\pm 0,21$ dan Hidayati (2017) 0,82 $\pm 0,18$. Adanya perbedaan di setiap ejakulasi disebabkan oleh pakan, umur, frekuensi penampungan dan faktor lainnya (Salmah, 2014). Warna sering dikaitkan dengan konsistensi (kekentalan) dan konsentrasi spermatozoa, semakin kental suatu semen maka konsentrasi spermatozoa semakin tinggi dan warna semen semakin kekuningan krem hasil warna kambing Sapera menunjukkan warna krem dengan konsistensi kental, hasil ini sesuai pada penelitian (Hastono dkk., 2013; Hidayati, 2017) bahwa semen kambing Sapera berwarna krem dengan konsistensi kental. Bau semen pada penelitian ini bau khas kambing yaitu prengus.

Tabel 1. Hasil pemeriksaan makroskopis dan mikroskopis semen segar kambing Sapera

\begin{aligned} & \hline Parameter Hasil Pengamatan \\ & \hline Volume $0,94 \pm 0,39 \mathrm{ml} \\ &$ Warna Krem \\ & Bau Khas \\ & Konsistensi Kental \\ & pH $6,5 \pm 0,52 \\ &$ Konsistensi $3681 \pm 539 \mathrm{juta} / \mathrm{ml} \\ &$ Gerakan massa $++/+++ \\ &$ Motilitas $76,00 \pm 0,04 \% \\ &$ Viabilitas $82,00 \pm 0,04 \% \\ &$\hline\end{aligned}

Tabel 2. Persentase motilitas dan viabilitas dalam tris kuning telur

\begin{tabular}{cccc}
\hline Variabel & Ulangan & P0 & P1 \\
\hline $\begin{array}{c}\text { Motilitas (\%) } \\
\text { (rerata } \pm \text { standar deviasi) }\end{array}$ & 9 & $76,11 \pm 4,17$ & $65,56 \pm 3,91$ \\
\hline $\begin{array}{c}\text { Viabilitas (\%) } \\
\text { (rerata } \pm \text { standar deviasi) }\end{array}$ & 9 & $82,33 \pm 4,06$ & $72,22 \pm 3,63$ \\
\hline
\end{tabular}

Keterangan: (P0) Semen segar; (P1) Tris kuning telur

Tabel 3. Persentase motilitas dan viabilitas dalam susu skim kuning telur

\begin{tabular}{cccc}
\hline Variabel & Ulangan & P0 & P2 \\
\hline $\begin{array}{c}\text { Motilitas (\%) } \\
(\text { rerata } \pm \text { standar deviasi) }\end{array}$ & 9 & $76,11 \pm 4,17$ & $61,11 \pm 4,17$ \\
\hline $\begin{array}{c}\text { Viabilitas (\%) } \\
\text { (rerata } \pm \text { standar deviasi) }\end{array}$ & 9 & $82,33 \pm 4,06$ & $67,78 \pm 3,87$ \\
\hline
\end{tabular}

Keterangan: (P0) Semen segar; (P1) Tris kuning telur

$\mathrm{pH}$ atau derajat keasaman diukur menggunakan $\mathrm{pH}$ meter, dengan rataan pada penelitian ini adalah $6,50 \pm 0,53$. Susilowati dkk., (2010) mengatakan $\mathrm{pH}$ normal pada kambing 6,4-6,8 dan menurut Kartasudjana (2001) semen kambing umumnya memiliki $\mathrm{pH}$ 5,9-7,0.

Penelitian Hidayati (2017) menunjukkan

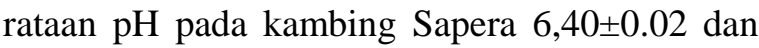
penelitian Kusumawati dkk., (2016) dan
Tambing dkk., (2000) semen kambing PE dengan nilai $\mathrm{pH} 7$.

Pemeriksaan konsentrasi dilakukan dengan menggunakan spektrofotometer dengan hasil $3681 \pm 0,54$ (juta/ml) hasil ini tidak jauh berbeda dengan penelitian Hidayati (2017) kambing Sapera 3677 (juta/ml), kambing PE 3540,2 (juta/ml) (Kusumawati dkk., 2016), kambing PE 3220 (juta/ml) (Riyadhi et al., 2017) dan kambing Boer 3298 (juta/ml) (Ihsan, 2013). Hal 
ini menunjukkan konsentrasi kambing masih dalam keadaan normal sesuai dengan Syahwal (2010) mengatakan untuk nilai konsentrasi spermatozoa pada kisaran 2000-6000 (juta/ml). Gerakan massa dinilai dengan besar gelombang, gelap, tebal dan pergerakan yang cepat. Hasil gerakan massa pada penelitian ini (+++) yang sesuai dengan penelitian (Hastono., dkk 2013; Hidayati, 2017) dimana semen kambing Sapera menghasilkan gerakan massa (+++) yang menunjukkan gerakan yang cepat, gelap dan tebal.Persentase viabilitas atau hidup mati dengan nilai $80,55 \pm 3,9$ dan persentase motilitas spermatozoa dengan hasil $76,00 \pm 0,04$ yang didapat motilitas lebih tinggi dibandingkan dengan laporan Hidayati (2017) yakni $75,41 \pm 0,96$ namun untuk viabilitas $80,00 \pm 1,17$. Pergerakan progresif spermatozoa yang menunjukkan tingkat daya hidup spermatozoa yang tinggi.

\section{Motilitas dan Viabilitas Semen Kambing Sapera pada Evaluasi Semen Segar dan Before Freezing dalam Pengencer Tris Kuning Telur}

Hasil motilitas dan viabilitas semen kambing Sapera pada evaluasi semen segar dan before freezing dalam pengencer tris kuning telur dapat dilihat pada tabel 2 .

Hasil uji T2 sampel dependent menunjukkan perbedaan yang sangat nyata $(\mathrm{p}<0,01)$ terhadap motilitas semen kambing Sapera pada evaluasi semen segar dan Before Freezing dengan pengencer tris kuning telur. Motilitas spermatozoa kambing Sapera terjadi penurunan dari motilitas semen segar spermatozoa $76,11 \pm 4,17$ menjadi $65,56 \pm 3,91$ dan viabilitas $82,33 \pm 4,06$ menjadi $72,22 \pm 3.63$ nilai tersebut menunjukkan motilitas dan viabilitas spermatozoa dapat bertahan pada tris kuning telur. Rizal dan Herdis (2005) mengatakan bahwa penurunan suhu $37^{\circ} \mathrm{C}-5^{\circ} \mathrm{C}$ yang merupakan proses pendinginan dimana spermatozoa harus beradaptasi kembali pada perubahan suhu yang terjadi. Menurut Sukmawati dkk., (2014) penurunan motilitas selama proses pembekuan yang terjadi perubahan suhu dan osmolalitas yang ekstrim sehingga merusak komposisi lipid membran plasma yang berdampak pada penurunan motilitas, namun dengan penambahan bahan pengencer dapat membantu mempertahankan membran plasma spermatozoa dari penurunan suhu.

Motilitas dan viabilitas spermatozoa kambing Sapera dapat bertahan dalam pengencer tris kuning telur evaluasi Before Freezing (Tabel 2) karena terdapat beberapa bahan penyangga dan sumber nutrisi dengan persentase lebih besar. Komposisi bahan penyangga dalam tris kuning telur adalah tris amino methane, asam sitrat, raffinosa dan kuning telur. Penyangga yang berfungsi mempertahan $\mathrm{pH}$ semen dari kejutan dingin (cold shock) karena pada proses metabolisme spermatozoa yang menghasilkan asam laktat, fruktosa sebagai energi bagi spermatozoa. Kandungan laktosa dalam tris kuning telur yang berfungsi sebagai sumber nutrisi bagi spermatozoa, laktosa yang dapat dimetabolisme pada proses glikolisis atau siklus krebs untuk menghasilkan energi adenosin triposphate (ATP), yang berfungsi untuk spermatozoa bergerak dan mempertahankan kehidupan spermatozoa (Rizal, 2009). Rafinosa adalah trisakarida yang merupakan gabungan dari galaktosa - glukosa - fruktosa yang dapat menyediakan lebih banyak sumber energi bagi spermatozoa (Rizal dkk., 2006), yang didukung oleh Savitri et al., (2014), trehalosa dan rafinosa yang ditambahkan ke dalam pengencer akan berasosiasi dengan karbohidrat yang ada pada selubung sel sehingga membran plasma dapat terlindungi dari kerusakan secara mekanik selama proses pengolahan semen berlangsung, terutama saat penyimpanan pada suhu rendah didukung oleh Nurlia (2016) bahwa rafinosa berpengaruh mempertahankan motilitas dan viabilitas spermatozoa sapi Ongole pada pengencer tris kuning telur before freezing. Tambing dkk., (2008) mengatakan bahwa persentase viabilitas spermatoza kambing Saanen pada proses sesudah pengenceran dan ekuilibrasi (Before Frezing) yang menggunakan tris kuning telur dapat mempertahankan viabilitas spermatozoa karena bahan penyangga dan lecithin yang terkandung didalam kuning 
telur dapat melindungi spermatoza dari cold shock dan Wiratri dkk., (2014) mengatakan bahwa viabilitas sapi pada proses pendinginan mendapatkan hasil terbaik dengan pengencer tris kuning telur dibandingkan dengan pengencer Susu skim kuning telur karena penambahan kuning telur $20 \%$ pada tris yang berfungsi sebagai krioprotektan ektraseluler melindungi spermatozoa selama pendinginan.

Motilitas dan Viabilitas Semen Kambing Sapera pada Evaluasi Semen Segar dan Before Freezing dalam Pengencer Susu Skim Kuning Telur

Hasil persentase motilitas dan viabilitas semen kambing Sapera pada evaluasi semen segar dan Before Freezing dalam pengencer tris kuning telur dapat dilihat seperti yang tertera pada tabel 3.

Pemeriksaan persentase motilitas dan viabilitas pada evaluasi semen segar dan Before Freezing spermatozoa dengan uji T2 sampel dependent menunjukkan perbedaan sangat nyata $(p<0,01)$. Berdasarkan hasil dari penelitian, motilitas spermatozoa kambing Sapera terjadi penurunan dari motilitas semen segardengan rataan $76,11 \pm 4,17$ menjadi $61,11 \pm 4,17$ dan viabilitas $82,33 \pm 4,06$ menjadi $67,78 \pm 3,87$. Rataan di atas menunjukkan spermatozoa dapat bertahan pada pengencer susu skim kuning telur yang masih bisa dilanjutkan pada proses pembekuan, namun rataan motilitas dan viabilitas spermatozoa pada susu skim kuning telur lebih rendah dibandingkan dengan tris kuning telur. Penurunan persentase motilitas spermatozoa seiring dengan lama waktu pendinginan dan ketersediaan nutrisi bagi spermatozoa (Arifiantini dkk., 2005). Menurut Suharyanti dkk., (2011) bahwa rendahnya persentase susu skim karena memiliki tingkat viskositas yang tinggi disebabkan kandungan lemak yang tinggi sehingga menghambat gerak spermatozoa dibandingkan tris kuning telur.

Viabilitas spermatozoa semen segar hingga evaluasi Before Freezing mengalami penurunan hal ini karena proses pendinginan akan menurunkan viabilitas spermatozoa. Cooter et al., (2005) mengatakan bahwa proses pendinginan menyebabkan spermatozoa merubah struktur dari fosfolipid membran plasma dan mengganggu fungsi dan permeabilitas membran sel. Menurut Sukmawati, dkk (2014) apabila terjadi kerusakan membran maka proses metabolisme akan terganggu, sintesa Adenosin Tri Fosfat (ATP) tidak berjalan lancar dan berakibat penurunan pada viabilitas spermatozoa. Suharyati dkk., (2011) bahwa persentase hidup spermatozoa pada susu skim kuning telur karena kandungan laktosa yang tinggi yang dapat mempercepat metabolisme spermatozoa sehingga terjadinya penumpukan asam laktat yang menjadi racun bagi spermatozoa sehingga banyaknya spermatozoa yang mati.

\section{KESIMPULAN}

Berdasarkan hasil penelitian dapat disimpulkan:

1. Persentase motilitas dan viabilitas spermatozoa kambing Sapera mengalami penurunan dalam media tris kuning telur dan susu skim kuning telur before freezing dari semen segar.

2. Spermatozoa kambing Sapera dapat dilakukan proses pembekuan menggunakan kedua bahan pengencer, namun tris kuning telur dapat mempertahankan spermatozoa kambing Sapera lebih baik dari susu skim kuning telur pada proses before freezing.

\section{UCAPAN TERIMA KASIH}

Penulis mengucapkan terima kasih kepada PSDKU Banyuwangi Universitas Airlangga atas ijin dan bantuan fasilitas dalam penelitian

\section{DAFTAR PUSTAKA}

Al-arif, M.A. 2016. Rancangan Percobaan. Fakultas kedokteran Hewan. Universitas Airlangga.

Allai, L., D. Xavier, C. Jesus, L. Noureddine, B.M. Moula, B. Abdelmoughit, E. 
Abdelkhalid, N. Boubker, and E.A. Bouchra. 2015. Effect of Argan Oil on Liquid Storage of Ram Semen in Tris or Skim Milk Based Extenders. Anim Reprod Sci, 160: 57-67.

Ari, U.C., R. Kulaksi, and Y. Ozturkler. 2011. Freezability of Tushin Ram Semen Extended with Goat or Cow Milk Based Extenders. Reprod Dom Anim, 46(6): 975-979.

Arifiantini, I., T.L. Yusuf, dan D. Yanti. 2005. Kajian Banding Kualitas Semen Beku Sapi Friesian Holstein Menggunakan Pengenceran dari Berbagai Balai Inseminasi Buatan di Indonesia. Anim Prod, 7(3): 168176.

Cooter, P.Z., H.A. Goolsby, and S.D. Prien 2005. Preliminary Evaluation of a Unique Freezing Technology for Bovine Spermatozoa Cryopreservation. Reprod Dom Anim, 40: 98-99.

Hardijanto., S. Susilowati., T. Hernawati., T. Sardjito, dan T.W. Suprayogi. 2010. Buku Ajar Inseminasi Buatan. Fakultas Kedokteran Hewan. Universitas Airlangga.

Hastono., U. Adiati, dan L. Praharani. 2013. Libido, Kemampuan Kawin dan Kualitas Sperma Kambing dari Tiga Bangsa. Seminar Nasional Teknologi Peternakan dan Veterinary :Balai Penelitian Ternak. Bogor. p345-348.

Herdis., I.W.A. Darmawan, dan M. Rizal. 2016. Penambahan Beberapa Jenis Gula Dapat Meningkatkan Kualitas Spermatozoa Beku Asal Epididimis Ternak Domba. J Ked Hewan, 10(2): 200-204.

Hidayati, H. 2017. Imbuhan Pentoxifylline dalam Pengencer Tris Kuning Telur dan Omega-3 dalam Pengencer Skim untuk Meningkatkan Kualitas Semen Beku Kambing Sapera [Tesis]. Program Studi Biologi Reproduksi. Institut Pertanian Bogor. Hal.12.
Juniandri., T. Susilawati, dan N. Isnaini. 2014. Perbandingan Pengenceran Andromed dan CEP-2 terhadap Kualitas Spermatozoa Sapi Hasil Seksing dengan Sentrifugasi gradient Densitas Percoll. J Vet, 15(2): 252-262.

Kartasudjana, R. 2001. Teknik Inseminasi Buatan Pada Ternak. Jakarta.

Kusumawati, D.E., H. Leondro, dan A.T.N. Krisnaningsih. 2016. Pengaruh Suhu dan Lama Simpan Semen Segar terhadap Motilitas dan Abnormalitas Spermatozoa Kambing Peranakan Etawa (PE). Seminar Nasional Hasil Penelitian. Hal.199-208.

Nurlia, I. 2016. Pengaruh Penambahan Dosis Rafinosa dalam Pengencer Tris kuning Telur Terhadap Motilitas, Persentase Hidup, dan Abnormalitas Spermatozoa Sapi Ongole [Skripsi]. Fakultas Pertanian. Universitas Lampung. Hal.48.

Praharani, L., U. Adiati, dan I.G.M. Budiarsana. 2013. Libido, Kemampuan Kawin dan Kualitas Sperma Kambing dari Tiga Bangsa. Seminar Nasional Teknologi Peternakan dan Veterinary :Balai Penelitian Ternak. Bogor. Hal.304-309.

Riyadhi, M., A. Setiawan., Herdis, and M. Rizal. 2017. Epididymal Spermatozoa Quality of Etawa Crossbreed Goat in Tris Extender Supplemented with Various Lactose Consentrations. J Ked Hewan, 11(1): 15-18.

Rizal, M. 2009. Daya Hidup Spermatozoa epididimis Sapi Bali yang Dispreservasi pada suhu $3-5^{\circ} \mathrm{C}$ dalam pengencer Tris dengan Konsentrasi Laktosa yang berbeda. JITV, 14: 142-149.

Rizal, M. dan Herdis. 2005. Daya Hidup Spermatozoa Epididimis Domba Garut yang Dikriopreservasi Menggunakan Modifikasi Pengunakan Pengencer Tris. Hayati, 12(2): 61-66. 
Rizal, M., Herdis, A. Boediono, A.S. Aku, dan Yulnawati. 2006. Peranan Beberapa Jenis Gula dalam meningkatkan Kualitas Semen Beku Domba Garut. JITV, 11(2): 123-130.

Salmah, N. 2014. Motilitas, Persentase Hidup dan Abnormalitas Spermatozoa Semen Beku Sapi Bali pada Pengenceran Andromed dan Tris Kuning Telur [Skripsi]. Fakultas Peternakan. Universitas Hasanuddin.

Savitri, A. Oriza, L. Y. Tuty, S. Dondin, dan R. I. Arifiantini. 2014. Kualitas Semen Cair Kambing Peranakan Etawah dalam Modifikasi Pengencer Tris dengan Trehalosa dan Rafinosa. Jurnal Veteriner, 15(1): 1122.

Soetarno, T. 2016. Budidaya Ternak Perah. Universitas Terbuka. Banten.

Suharyati, S. dan M. Hartono. 2011. Preservasi dan Krioprotektan Semen Sapi Limousin dalam Berbagai Bahan Pengencer. J Ked Hewan, 5(2): 53-58.

Sukmawati, E., R. I. Arifiantini, dan dan B. Purwantara. 2014. Daya Tahan Spermatozoa terhadap Proses Pembekuan pada Berbagai Jenis Sapi Pejantan Unggul. JITV, 9(3): 168-175.

Supriyati., R. Krisnan, dan L. Praharani. 2015. Konsumsi Nutrein, Produksi Susu dan Komposisi Tiga Genotipe Kambing Perah. Prosiding Seminar Nasional Teknologi
Peternakan dan Veterinary: Balai Penelitian

Ternak. Bogor. p357-363.

Susilowati, S. Hardijanto., T.W. Suprayogi., T. Sardjito, dan T. Hernawati. 2010. Penuntun Pratikum Inseminasi Buatan. Fakultas Kedokteran Hewan. Universitas Airlangga.

Sutama, I.K. dan IGM. Budiarsana. 2017. Kupas Tuntas Beternak Kambing. Jakarta Timur: Penebar Swadaya.

Syawal, M. 2010. Karakteristik Morfologi Produksi Kambing Boer, Kacang dan Persilangan Pada Umur 0-3 Bulan (Prasapih). Seminar Nasional Teknologi dan Veteriner. p617-619.

Tambing, S.T., I.K. Sutama, dan M. Sariubang. 2008. Efektivitas Konsentrasi Kuning telur di dalam Pengenceran Tris dengan dan tanpa Plasma Semen terhadap Kualitas Semen Beku Kambing Saanen. JITV, 13(4): 315-322.

Tambing, S.T., M.R. Toelihere., T.L. Yusuf, dan I.K. Sutama. 2000. Pengaruh Gliserol dalam Pengencer Tris Terhadap Kualitas Semen Beku Kambing Peranakan Etawa. JITV, 5(2): 1-8.

Wiratri, D.B.V., T. Susilawatidan, S. Wahjuningsih. 2014. Kualitas Semen Sapi Limousin pada Pengencera yang Berbeda Selama Pendinginan. J Ter Trop, 15(1): 1320. 